Article

\title{
Silicon Oxycarbide-Graphite Electrodes for High-Power Energy Storage Devices
}

\author{
Dominik Knozowski ${ }^{1}{ }^{\mathbb{B}}$, Magdalena Graczyk-Zajac ${ }^{2,3}$, Grzegorz Trykowski ${ }^{4} \mathbb{D}$ and \\ Monika Wilamowska-Zawłocka ${ }^{1, * \text { (D) }}$ \\ 1 Department of Energy Conversion and Storage, Faculty of Chemistry, Gdańsk University of Technology, \\ Narutowicza 11/12, 80-233 Gdańsk, Poland; dominik.knozowski@pg.edu.pl \\ 2 Fachbereich Material und Geowissenschaften, Technische Universität Darmstadt, Otto-Berndt-Straße 3, \\ 64287 Darmstadt, Germany; graczyk@materials.tu-darmstadt.de \\ 3 EnBW Energie Baden-Württemberg AG, Fettweisstraße 44, 76189 Karlsruhe, Germany \\ 4 Faculty of Chemistry, Nicolaus Copernicus University in Torun, 87-100 Torun, Poland; tryki@umk.pl \\ * Correspondence: monika.wilamowska@pg.edu.pl; Tel.: +48-58-347-24-74
}

Received: 1 September 2020; Accepted: 23 September 2020; Published: 26 September 2020

check for updates

\begin{abstract}
Herein we present a study on polymer-derived silicon oxycarbide (SiOC)/graphite composites for a potential application as an electrode in high power energy storage devices, such as Lithium-Ion Capacitor (LIC). The composites were processed using high power ultrasound-assisted sol-gel synthesis followed by pyrolysis. The intensive sonication enhances gelation and drying process, improving the homogenous distribution of the graphitic flakes in the preceramic blends. The physicochemical investigation of SiOC/graphite composites using X-ray diffraction, ${ }^{29} \mathrm{Si}$ solid state NMR and Raman spectroscopy indicated no reaction occurring between the components. The electrochemical measurements revealed enhanced capacity (by up to 63\%) at high current rates $\left(1.86 \mathrm{~A} \mathrm{~g} \mathrm{~g}^{-1}\right.$ ) recorded for SiOC/graphite composite compared to the pure components. Moreover, the addition of graphite to the SiOC matrix decreased the value of delithiation potential, which is a desirable feature for anodes in LIC.
\end{abstract}

Keywords: Silicon Oxycarbide (SiOC); graphite; composites; energy storage; lithium-ion capacitor (LIC)

\section{Introduction}

Over the past few years, there has been increasing interest in small high-power energy storage devices. For these applications electrochemical capacitors (ECs) are considered to be more suitable than conventional batteries. Unfortunately, ECs possess much lower energy density in comparison to batteries, namely 3-6 $\mathrm{Wh} \mathrm{kg}^{-1}$ vs. 150-200 $\mathrm{Wh} \mathrm{kg}^{-1}$, respectively [1,2], which severely limits their broader application. Many attempts have been made to enhance ECs energy density. Realizing an asymmetric system by employing a Faradaic, battery-like anode as a negative electrode is one of the most promising concepts. This idea was first presented by Amatucci in 2001 [3], and it is commonly known as an EC-battery hybrid or lithium-ion capacitor (LIC).

The main advantage of using a battery-like anode instead of the typical EC's electrode is the extension of the overall potential difference. ECs operates from 0 to $2.7 \mathrm{~V}$ (in organic electrolytes) in charge/discharge processes, which results in diminishing potential difference between the electrodes during cycling and hence in limited energy density [4]. On the contrary, battery-like anodes hold constant potential during charge/discharge, which allows for keeping a higher potential difference over the entire cycling process. LIC preserves high power of EC thanks to processes separation-lithiation/delithiation occurs in anode and $\mathrm{PF}_{6}^{-}$adsorption/desorption on cathode [5-9]. However, due to differences in 
electrochemical characteristics between electrodes, it is necessary to make proper electrodes matching in design.

On the anodic side, a few requirements must be met. The material should be characterized by a good conductivity, low lithiation/delithiation potential and provide sufficient capacity [3]. The capacity does not have to be exceptionally high, since it is often limited by the cathode [10,11], but at least $50 \mathrm{mAh} \mathrm{g}^{-1}$ should be available at potentials below $2 \mathrm{~V} \mathrm{vs}$. $\mathrm{Li} / \mathrm{Li}^{+}$. The material should exhibit excellent rate capability to match the pace of cathodic reaction, and withstand polarization with $1-2 \mathrm{~A} \mathrm{~g}^{-1}$ for at least a few hundred cycles [11].

Having these requirements in mind, several solutions have been tested, specifically those originally applied in lithium-ion batteries. Various materials, based on $\mathrm{Li}_{4} \mathrm{~T}_{5} \mathrm{O}_{12}$ (LTO) [3,12], transition metal oxides/graphene composites $\left(\mathrm{Ni}_{2} \mathrm{O}_{5}, \mathrm{MnO}_{2}, \mathrm{CoO}\right)$ [13-15], transition metal sulfides ( $\left.\mathrm{MoS}_{2}, \mathrm{CoS}\right)$ [16,17] or carbonaceous materials (hard carbon, soft carbon, graphite) [18-20] are reported as potential anodes for LIC. However, most of them, except for carbonaceous materials, exhibit a relatively high delithiation potential (approximately $1.5 \mathrm{~V}$ ), which combined with low the capacity of a cathode does not provide high energy. Graphite exhibits very low lithiation potential: $0.005-0.25 \mathrm{~V} \mathrm{vs}$. $\mathrm{Li} / \mathrm{Li}^{+}$. Moreover, graphite is abundant, non-toxic, has good cycle life and has a decent capacity for LIC applications. However, the performance of graphite in LIC is limited by its poor rate capability. Thus, many works have been focused on the improvement of the rate capability of graphite. To enhance the rate capability, various coatings [21], modifications of particle size, shape and porosity [22,23] or doping with various functional groups, nanoparticles or nanostructures have been reported [24,25]. Still, an unexplored solution is combining graphite with polymer-derived ceramics (PDCs). PDCs, including silicon oxycarbide ( $\mathrm{SiOC}$ ) and silicon carbon nitride $(\mathrm{SiCN})$, are the materials consisting of $\mathrm{SiC}_{\mathrm{x}} \mathrm{O}_{\mathrm{y}}$ or $\mathrm{SiC}_{\mathrm{x}} \mathrm{N}_{\mathrm{y}}$ $(x, y=0-4)$ structural units, respectively, and a free carbon phase [26]. PDCs can be prepared by various routes, including liquid routes such as sol-gel, hydrosilylation or photocrosslinking, followed by a pyrolysis process. The liquid route allows facile mixing with other materials for making homogeneous composites. Pure PDCs have been tested as a material for lithium-ion batteries [27-29] and lithium-ion capacitors [30] as they exhibit high capacity up to $920 \mathrm{mAh} \mathrm{g}^{-1}$, good cyclability and good rate capability. PDCs have also been considered as an electrochemically active and mechanically resistant matrix for lithium-alloying compounds such silicon [31,32], tin [33,34] or antimony [35,36]. It has already been demonstrated by Kolb et al. [37] and Graczyk-Zajac et al. [38] that a combination with PDCs improves electrochemical properties of graphite. In this system, PDCs serve as a matrix, protecting graphite from deterioration. There are a number of works reporting the successful enhancement of materials' energy storage properties via blending PDCs with carbonaceous materials, such as SiCN-graphite [37,38], SiCN-carbon nanotubes [39], SiCN-hard carbons [40,41], SiOC-carbon nanofibers [42], SiOC-CNTs [43] and SiOC-graphene [44]. However, to date there are still very few reports concerning SiOC-graphite composites and, to the best of our knowledge, no reports concerning the utilization of SiOC/graphite composite for LIC. The main advantage of SiOCs over SiCNs is the higher resistance of the preceramic polymer against oxidation, which facilitates material production $[45,46]$.

In this work we investigate novel SiOC/graphite composites with phenyltriethoxysilane (PhTES) as the preceramic precursor. PhTES-based silicon oxycarbide exhibits high capacity and good rate capability [47]. We applied a new approach to blend the starting materials, namely, sol-gel synthesis enhanced by high-power ultrasounds. Sonication ensured good dispersion of graphite within the green body and accelerated gelation and drying processes. The new SiOC/graphite composite exhibited improved rate capability and high capacity in a lower potential range than pure SiOC, which makes it a promising candidate for negative electrodes in LIC.

\section{Experimental Part}

\subsection{Synthesis of Composites}

Silicon oxycarbide samples and the SiOC-based composites were synthesized by the sol-gel method, followed by pyrolysis. Phenyltriethoxysilane (PhTES) (>97\%, Sigma Aldrich, Baden-Württemberg, 
Germany) was used as preceramic precursor. Different amounts of graphite powder (flakes, $<20 \mu \mathrm{m}$, synthetic, Sigma Aldrich, Baden-Württemberg, Germany) were added to the synthesis solution to obtain SiOC/graphite composites of various carbon content. The synthesis procedure was as follows. First, graphite was poured into a three-neck flask. Graphite amount varied from 0 (pure ceramic sample-Denoted as $\mathrm{SiOC}_{\mathrm{PhTES}}$ ), through 2, 4 and $10 \mathrm{~g}$ (composite samples denoted as $\mathrm{SiOC}_{\mathrm{PhTES}} / \mathrm{C}_{2 \mathrm{~g}}$, $\mathrm{SiOC}_{\mathrm{PhTES}} / \mathrm{C} 4 \mathrm{~g}$, and SiOC PhTES $_{\mathrm{C}} \mathrm{C} 10 \mathrm{~g}$, respectively). Then, $17.3 \mathrm{~g}$ of PhTES and $6.6 \mathrm{~g}$ of absolute ethanol were added and carefully stirred. Next, $3.9 \mathrm{~g}$ of acidic water $(\mathrm{pH}=4.5)$ were poured dropwise. Suspension was boiled for $1.5 \mathrm{~h}$, then cooled down and transported into propylene test tubes. Afterwards, obtained sols were sonicated using high power homogenizer (UP200St, Hielscher Ultrasound Technology, Teltow, Germany) to obtain tar-like gel. Next, gels were dried for 5 days, with temperature increasing from $80^{\circ} \mathrm{C}$ to $120^{\circ} \mathrm{C}$. The final step was pyrolysis at $1000^{\circ} \mathrm{C}$ under argon atmosphere (heating ratio $100^{\circ} \mathrm{C} / \mathrm{h}$, dwell time $1 \mathrm{~h}$, constant Ar flow of $40 \mathrm{~mL} \mathrm{~min}^{-1}$ ).

\subsection{Electrode Preparation and Electrochemical Measurements}

Ceramic composites were ball milled (Mixer Mill, MM200, Retsch, Haan, Germany) to obtain fine powder. Then, powder was mixed with $10 \mathrm{wt}$.\% solution of polyvinylidene fluoride (PVDF, Solef6020, Solvay, Rheinberg, Germany) dissolved in N-methyl 2-pyrrolidone (NMP) (BASF, Ludwigshafen, Germany) and Carbon Black Super $P^{\circledR}$ (Imerys Graphite \& Carbon, Bodio, Swizerland). The ratio between powder, PVDF and carbon black was 85:10:5. In addition, 1-2 $\mathrm{g}$ of NMP were added for proper consistency. As received slurry was uniformly distributed onto a copper foil $(10 \mu \mathrm{m}$, Copper SE-Cu58 Schlenk Metallfolien GmbH \& Co. KG, Roth, Germany) using the doctor blade technique to obtain $\sim 100 \mu \mathrm{m}$ thick layers. Layers were then dried at $80^{\circ} \mathrm{C}$ and punched into $10 \mathrm{~mm}$ discs. So, prepared disc electrodes were further dried at $80^{\circ} \mathrm{C}$ under vacuum and transferred into a glove box (MBraun Glove Box Systems) where the cells were assembled.

For electrochemical testing Swagelok ${ }^{\circledR}$ type two-electrode testing cells were assembled. In this system we used a disc electrode of the active material as a working electrode, a quartz filter paper MN GF-2 (45 $\mu \mathrm{m}$, Macherey-Nagel GmbH \& Co. KG, Roth, Germany) as a separator, a $1 \mathrm{M} \mathrm{LiPF}_{6}$ in 1:1 v/v ethylene carbonate:dimethyl carbonate (Sigma-Aldrich, Baden-Württemberg, Germany) as an electrolyte and a lithium foil (Sigma Aldrich, Baden-Württemberg, Germany) as a counter/reference electrode.

The materials were tested by cyclic voltammetry (CV) and galvanostatic charge-discharge (GCD) with potential limitation techniques. Electrochemical measurements were performed on the Biologic Potentiostat SP200 (BioLogic Science Instruments, Seyssinet-Pariset, France) while long-time cycle stability was conducted using a multichannel battery interface (Atlas 0961, Atlas Solllich, Rębiechowo, Poland). The potential window was set between $0.005 \mathrm{~V}$ and $3 \mathrm{~V} \mathrm{vs.} \mathrm{Li}^{-\mathrm{Li}^{+}}$for both techniques. Materials were charged/discharged with the same current rate $\left(I_{\text {charge }}=I_{\text {discharge }}\right)$. Cyclic voltammetry was carried out with a scan rate of $0.1 \mathrm{mV} \mathrm{s}^{-1}$.

\subsection{Characterization Techniques}

Elemental analysis was conducted on a carbon analyzer (Leco C-200, Leco Corporation, St. Joseph, MI, USA) and a nitrogen/oxygen analyzer (Leco TC-436, Leco Corporation, St. Joseph, MI, USA). Carbon and oxygen content were measured directly while the silicon content was calculated as a complement to $100 \%$. Thermal gravimetric analysis was performed on the SDT 2960 Simultaneous (TA Instruments, New Castle, DE, USA). X-ray diffraction spectra were obtained from the powder diffractometer Stoe STADI P equipped with a Mo K $\alpha$ anode. Micro-Raman analysis within the wavenumber range of 100-3200 $\mathrm{cm}^{-1}$ was carried out using a confocal micro-Raman spectrometer (InVia, Renishaw, Wotton-under-Edge, UK) with an argon ion laser $(514 \mathrm{~nm})$. Raman spectra were deconvoluted using the OriginPro2016 software after the background subtraction. All the bands were fitted using Lorentzian peaks, except the D3 band, where a Gaussian curve was used. XPS analysis was carried out on the Escalab 250Xi spectroscope (Thermo-Fischer Scientific, Waltham, MA, USA) 
with a monochromatic $\mathrm{Al} \mathrm{K} \alpha$ source. The morphology was characterized by a transmission electron microscope TEM (FEI, G2 F20X-Twin 200 kV, FEG, Hillsboro, OR, USA). Energy-dispersive X-ray spectroscopy EDS (EDAX, RTEM model SN9577, $134 \mathrm{eV}$ ) was used to identify the chemical elements in designated areas. Measurements were made in the TEM mode (bright-field) and the STEM mode (HAADF and EDX detectors). Preparation of the samples was as follows: a few milligrams of the powder were dispersed in ethanol (99.8\% anhydrous) with the aid of ultrasounds for $5 \mathrm{~s}$, and a drop of the dispersion $(5 \mathrm{~mL}$ ) was applied on a carbon-coated copper mesh with holes (Lacey type Cu 400 mesh, Plano, TX, USA), and stored in the room temperature until the complete evaporation of solvent. MAS-NMR measurements were performed on the Bruker Avance Ultrashield $500 \mathrm{MHz}$ spectrometer. ${ }^{29} \mathrm{Si}$ NMR spectra were recorded with the following parameters: single pulse sequence, ${ }^{29} \mathrm{Si}$ frequency: 139.11 MHz, $\pi / 8$ pulse length: $2.5 \mathrm{~ms}$, recycle delay: $100 \mathrm{~s}, 1 \mathrm{k}$ scans, external secondary reference: DSS. $3.2 \mathrm{~mm}$ zirconia rotors filled with samples were spun at $8 \mathrm{kHz}$ under air flow.

\section{Results and Discussion}

Figure 1 presents the thermographs of the investigated materials, i.e., $S_{\text {iOC }}$ PhTES, $S_{\text {SiOC }}$ PhTES/C2g, $\mathrm{SiOC}_{\mathrm{PhTES}} / \mathrm{C} 4 \mathrm{~g}$, and $\mathrm{SiOC}_{\mathrm{PhTES}} / \mathrm{C} 10 \mathrm{~g}$. The analysis provides information about mass loss during the pyrolysis process. It shows the influence of graphite addition on a thermal conversion yield of polymer/graphite blends. Pure $S_{\text {SiOC }}$ PhTES exhibited two significant mass losses: the first one between $50{ }^{\circ} \mathrm{C}$ and $350{ }^{\circ} \mathrm{C}$, and the second one in the temperature range of $400-600^{\circ} \mathrm{C}$. The first one is attributed to the release of by-products of the polycondensation reaction and the residual $\mathrm{EtOH} / \mathrm{H}_{2} \mathrm{O}$. The second one is related to the mass loss occurring during the redistribution reaction, i.e., the exchange of Si-O bonds with $\mathrm{Si}-\mathrm{H}$ and/or $\mathrm{Si}-\mathrm{C}$ bonds, with the simultaneous release of volatile compounds, mainly $\mathrm{H}_{2}, \mathrm{CH}_{4}$ or $\mathrm{C}_{2} \mathrm{H}_{2}[48,49]$. The overall ceramic yield of SiOC $\mathrm{PhTES}$ was around $60.9 \%$, which stays in accordance with the literature $[47,50]$. When graphite was added to the material, we observed a proportional

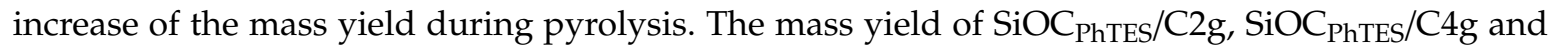
$\mathrm{SiOC}_{\mathrm{PhTES}} / \mathrm{C} 10 \mathrm{~g}$ was equal to $77.4 \%, 79.5 \%$ and $83.7 \%$, respectively. This is mostly related to a smaller mass loss in the temperature range of $400-500{ }^{\circ} \mathrm{C}$, which is a consequence of a lower PhTES content in the preceramic polymer/graphite blends. These results indicate that the content of graphite in the preceramic matrix did not change during pyrolysis in an argon atmosphere, and the final mass yield was directly related to the starting material composition.

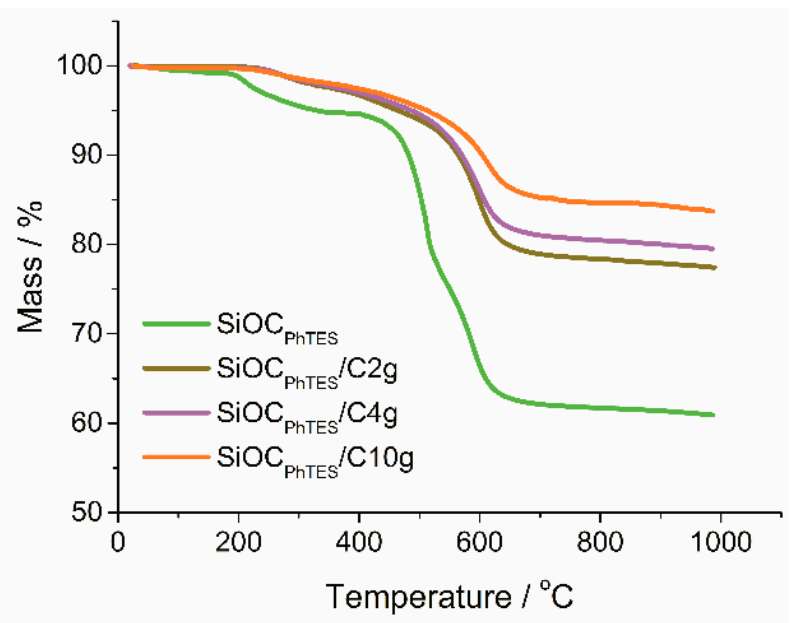

Figure 1. Dependence of the mass yield on the temperature of the SiOC/graphite composites.

The TGA results stay in agreement with the results of the elemental analysis shown in Table 1. As expected, the increase in the amount of graphite in the preceramic blends led to a higher amount of carbon in a final ceramic composite. Free carbon content in the pure $S i O C_{P h T E S}$ ceramic, calculated using the approach of Soraru et al. [51], was $34.2 \mathrm{wt} \%$, which represents $91 \%$ of the total carbon in the sample. 
For the SiOC/graphite composites, the free carbon phase constituted from $95 \%$ (for $\mathrm{SiOC}_{\mathrm{PhTES}} / \mathrm{C} 2 \mathrm{~g}$ ) to almost $100 \%$ (for $\mathrm{SiOC}_{\mathrm{PhTES}} / \mathrm{C} 10 \mathrm{~g}$ ) of the total carbon.

Table 1. Results of elemental analysis of SiOC $\mathrm{PhTES}$ and SiOC $\mathrm{PhTES} /$ graphite composites.

\begin{tabular}{cccccc}
\hline \multirow{2}{*}{ Material } & $\mathbf{C}$ & $\mathbf{O}$ & $\mathbf{S i}$ & $\mathrm{C}_{\text {free }}$ & \multirow{2}{*}{ Empirical Formula } \\
\cline { 2 - 5 } & \multicolumn{5}{c}{ wt.\% } \\
\hline SiOC $_{\text {PhTES }}$ & 37.4 & 29.3 & 33.3 & 34.2 & $\mathrm{SiO}_{1.546} \mathrm{C}_{2.632}$ \\
\hline $\mathrm{SiOC}_{\mathrm{PhTES}} / \mathrm{C} 2 \mathrm{~g}$ & 51.3 & 22.9 & 25.8 & 48.7 & $\mathrm{SiO}_{1.537} \mathrm{C}_{4.604}$ \\
$\mathrm{SiOC}_{\mathrm{PhTES}} / \mathrm{C} 4 \mathrm{~g}$ & 55.9 & 22.5 & 21.6 & 55.1 & $\mathrm{SiO}_{1.825} \mathrm{C}_{6.055}$ \\
$\mathrm{SiOC}_{\mathrm{PhTES}} / \mathrm{C} 10 \mathrm{~g}$ & 68.7 & 16.6 & 14.7 & 68.5 & $\mathrm{SiO}_{1.968} \mathrm{C}_{10.877}$ \\
\hline
\end{tabular}

${ }^{29}$ Silicon Solid-state NMR measurements $\left({ }^{29} \mathrm{Si}\right.$ MAS-NMR) were conducted in order to determine the change in the redistribution of various $\mathrm{SiO}_{x} \mathrm{C}_{y}$ tetrahedra units resulting from the addition of graphite. Figure 2 shows the corresponding ${ }^{29} \mathrm{Si}$ MAS-NMR spectra of $\mathrm{SiOC}_{\mathrm{PhTES}}$ and $\mathrm{SiOC}_{\mathrm{PhTES}} / \mathrm{C} 2 \mathrm{~g}$. The ${ }^{29} \mathrm{Si}$ MAS-NMR spectrum of the $\mathrm{SiOC}_{\mathrm{PhTES}} / \mathrm{C} 2 \mathrm{~g}$ composite exhibits broader peaks at approximately $-109,-73$ and $-48 \mathrm{ppm}$, and higher noise than the spectrum of the pure SiOC ${ }_{\text {PhTES }}$ ceramic sample. However, the share of $\mathrm{SiO}_{4}$ and mixed bonds $\mathrm{SiO}_{3} \mathrm{C}, \mathrm{SiO}_{2} \mathrm{C}_{2}$ tetrahedra is comparable for both samples (Table 2 and ref. [47]). $\mathrm{SiO}_{4}$ tetrahedra dominate in both samples $(76 \%-78 \%)$, and the mixed bonds constitute from several up to over a dozen percent. This suggests that there was no reaction between the preceramic polymer and graphite at any of the stages of preparation of the composites, namely during hydrolysis and condensation reactions, high-power ultrasound-assisted gelation process, nor pyrolysis at $1000^{\circ} \mathrm{C}$.

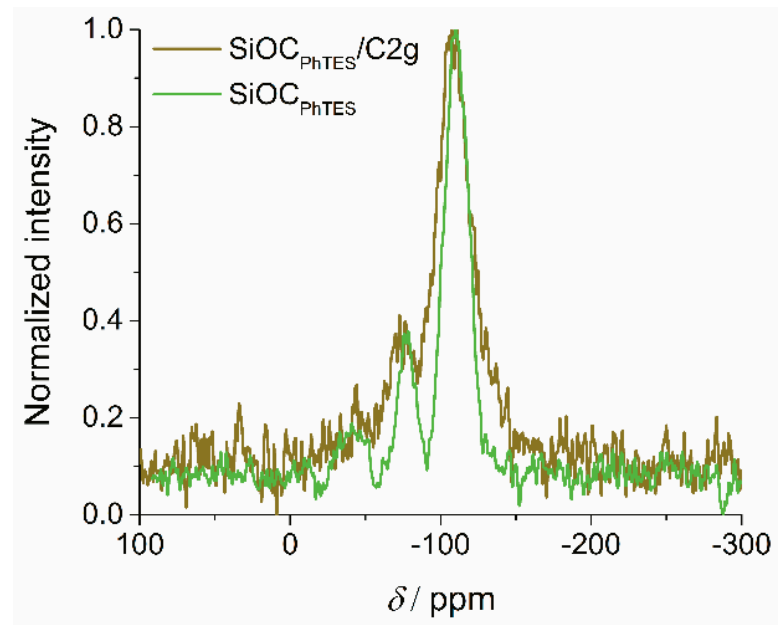

Figure 2. ${ }^{29} \mathrm{Si}$ MAS-NMR spectra of the SiOC $\mathrm{PhTES}$ and $\mathrm{SiOC}_{\mathrm{PhTES}} / \mathrm{C} 2 \mathrm{~g}$ samples.

Table 2. Data obtained from fitting of ${ }^{29} \mathrm{Si}$ MAS-NMR spectra of the pure ceramic and the composite samples.

\begin{tabular}{ccccccc}
\hline \multirow{2}{*}{ Sample } & \multicolumn{2}{c}{$\underline{\mathrm{SiO}}_{4}$} & \multicolumn{2}{c}{$\underline{\mathrm{SiO}}_{3} \mathrm{C}$} & \multicolumn{2}{c}{$\mathrm{SiO}_{2} \mathrm{C}_{2}$} \\
\cline { 2 - 7 } & $\delta / \mathbf{p p m}$ & $\%$ & $\delta / \mathbf{p p m}$ & $\%$ & $\delta / \mathbf{p p m}$ & $\%$ \\
\hline \multirow{2}{*}{ SiOC $_{\text {PhTES }}{ }^{\mathrm{a}}$} & -104.6 & 76.0 & -69.9 & 16.4 & -22.1 & 0.6 \\
$\mathrm{SiOC}_{\mathrm{PhTES}} / \mathrm{C} 2 \mathrm{~g}$ & -109.0 & 78.2 & -73.0 & 11.0 & -48.2 & 7.1 \\
\hline \multicolumn{4}{c}{${ }^{\mathrm{a}}$ results from our previous work [47]. }
\end{tabular}

XPS results (presented in Supplementary Materials-SM, Figure S1) confirm the collected NMR data. XPS Si2p spectra of pure ceramic and the composite samples look almost the same. A broad 
peak fitted with the $\mathrm{Si} 2 \mathrm{p}_{3 / 2}$ and Si2 $\mathrm{p}_{1 / 2}$ doublet at binding energies of 103.2-103.4 and 103.7-103.8 eV, respectively, corresponding to $\mathrm{SiO}_{4}$ tetrahedra [52,53] is observed. On the other hand, the C1s spectra of the pure ceramic sample and SiOC/graphite composite show some differences in the share of particular bonds. Both C1s spectra (Figure S2) were deconvoluted with four peaks at BE: $284.0-284.4 \mathrm{eV}$, 285.2-285.4 eV, 286.5-286.7 eV and 288.8-289.2 eV, which may be attributed to C-Si/C=C, C-C/C-H, $\mathrm{C}-\mathrm{O}$ and $\mathrm{C}=\mathrm{O}$ bonds, respectively [54-57]. However, the C1s spectrum of the SiOC/graphite composite shows a significantly larger peak corresponding to the $\mathrm{C}-\mathrm{C}$ bond, and smaller peaks assigned to the $\mathrm{C}-\mathrm{Si}, \mathrm{C}-\mathrm{O}$ and $\mathrm{C}=\mathrm{O}$ bonds, which is related to a high graphite content in the composite.

The homogenization method applied for blending of the materials requires high power ultrasound, which can have a destructive effect on the graphite structure. To evaluate possible changes in the graphite lattice XRD measurements were performed. Figure 3 shows the diffractograms of pure graphite, ceramic, and $\mathrm{SiOC}_{\mathrm{PhTES}} /$ graphite composites. For the graphite sample sharp peaks at $12^{\circ}$, $19.1^{\circ}, 20.1^{\circ}$ and $33.5^{\circ}$ ( $2 \theta \mathrm{Mo} \mathrm{K} \alpha$, which correspond to $26.2,42.2,44.5$ and 77.4 for $\mathrm{Cu} \mathrm{K} \alpha$ ) can be distinguished, described in literature as [2], [100], [101] and [110] Bragg peaks of typical hexagonal graphite $[58,59]$. In contrast, pure $\mathrm{SiOC}_{\mathrm{PhTES}}$ diffractograms show only a broad halo typical for amorphous materials $[51,60]$, while for the SiOC/graphite composites the peaks typical for graphite appear. The higher amount of graphite in the composite, the more pronounced reflexes in the diffractograms are detected. The diffractogram of $\mathrm{SiOC}_{\mathrm{PhTES}} / \mathrm{C} 10 \mathrm{~g}$ exhibits sharp peaks, which indicate that the skeleton of the graphite structure was preserved despite the usage of high-power ultrasounds during the synthesis.

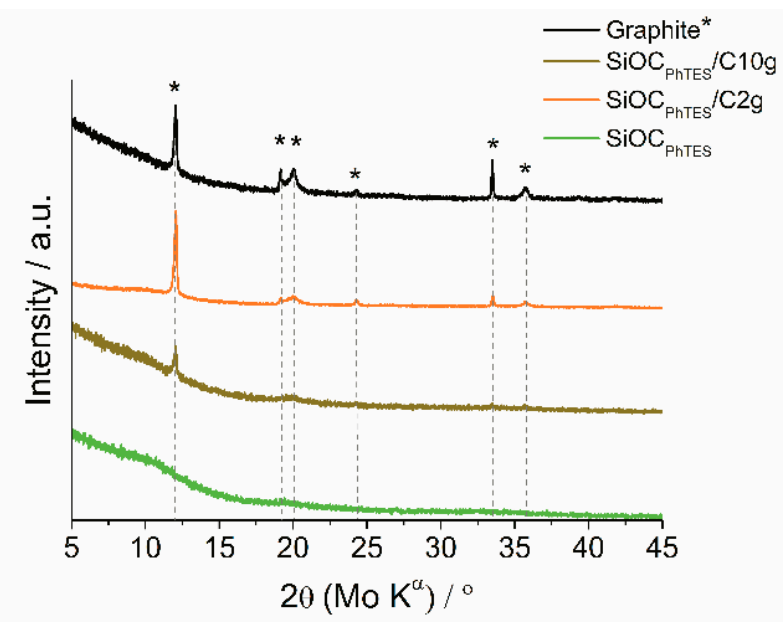

Figure 3. Diffractograms of pure graphite, ceramic and SiOC/graphite composites. ${ }^{*}$ is in the legend of the graph, meaning the diffraction peaks for graphite.

More detailed analysis of the carbon microstructure was performed by means of Raman spectroscopy. Figure 4a depicts Raman spectra of the investigated samples recorded in the range of $500-3000 \mathrm{~cm}^{-1}$ after the background subtraction. Two characteristic bands in the first-order spectra, namely the D-band at approximately $1333 \mathrm{~cm}^{-1}$, and the G-band at $1575 \mathrm{~cm}^{-1}$, representing disordered and graphitic carbon, respectively, appear for all of the investigated composites. In order to perform a quantitative analysis of the measured spectra, we deconvoluted the first-order Raman signals into five peaks (Figure 4b-e), namely D1, D2, D3, D4 and G according to [61,62].

In the spectra of the pure ceramic and the composites samples, the D band is separated into a main D1 peak and a small shoulder marked as D4. Both peaks, i.e., D1 and D4, result from a graphitic lattice vibration mode with $\mathrm{A}_{1 \mathrm{~g}}$-symmetry, which is typical for disordered carbons. D1 is assigned to graphene edges [63-65] while the D4 is related to Csp ${ }^{2}-\mathrm{Csp}^{3}$ bonds [66] or ionic impurities [67]. The $\mathrm{G}$ band was deconvoluted into a $\mathrm{G}$ peak, arising from stretching vibrations of the $\mathrm{sp}^{2}$-carbon bond in the ideal graphitic lattice ( $\mathrm{E}_{2 \mathrm{~g}}$ symmetry), and a D2 peak, related to the defected 
graphitic lattice (also $\mathrm{E}_{2 \mathrm{~g}}$ symmetry) $[61,64,65]$ and Stone-Wales defects [68], which is also present in the deconvoluted spectrum of the pure graphite sample (Figure S3a in Supplementary Materials). Moreover, between the D1 and G bands another band, namely a D3 band at $1525 \mathrm{~cm}^{-1}$, sp ${ }^{2}$ amorphous forms of carbon [61,62], is detected. Detailed information on band parameters is given in Table 3 and Table S1 in the Supplementary Materials.

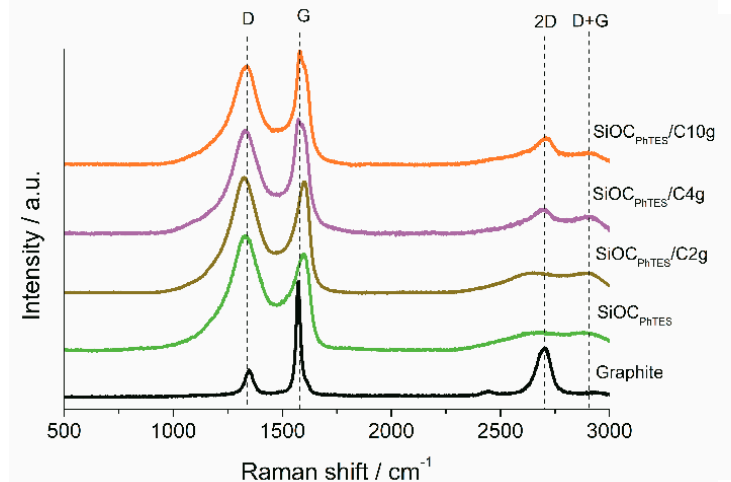

(a)

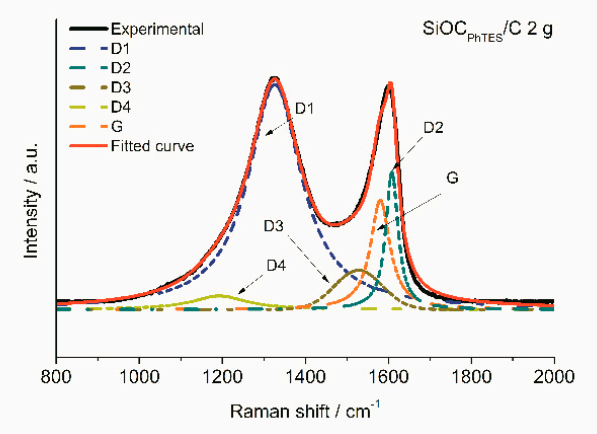

(c)

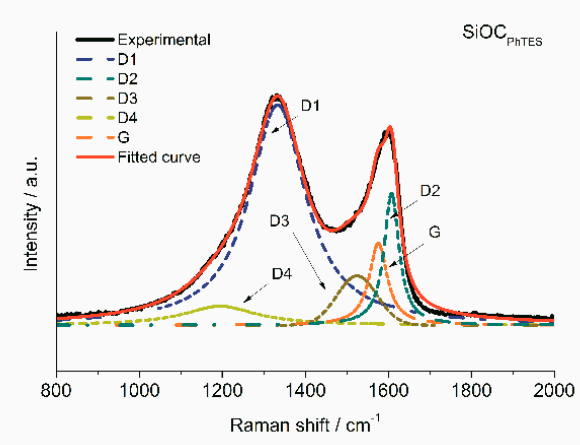

(b)

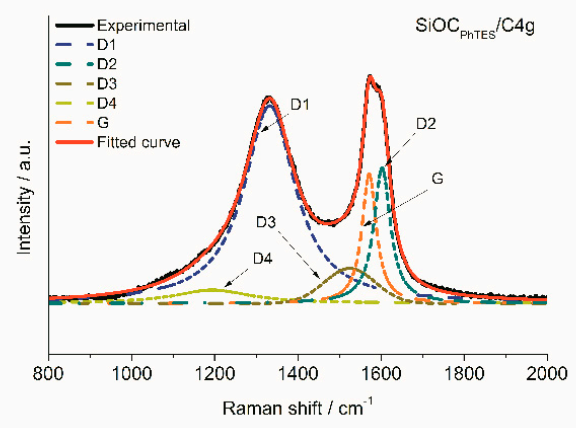

(d)

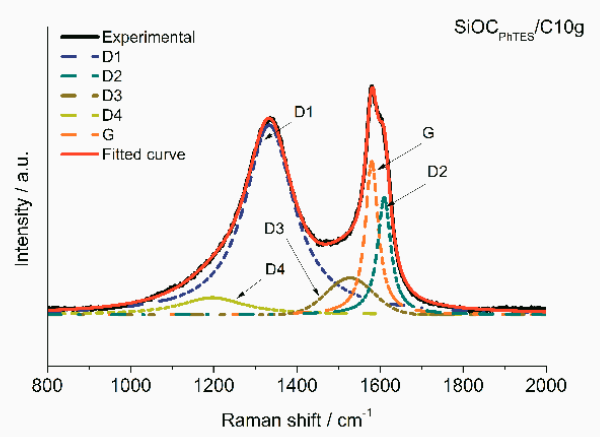

(e)

Figure 4. (a) Comparison of Raman spectra recorded for investigated samples. Fitting of the Raman

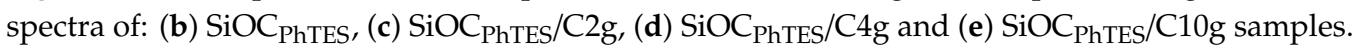

With the increasing amount of graphite in the composites one can notice a significant rise in the $\mathrm{G}$ band intensity, from 0.36 for the pure ceramic SiOC PhTES $_{\text {to }} 0.68$ for SiOC PhTES/C10g, along with a decrease in the intensity of the D1 and D4 bands, from 0.98 to 0.84 and from 0.084 to 0.075 for these materials, respectively. These differences are even more pronounced when we compare the $I_{\mathrm{D} 1} / I_{\mathrm{G}}$ and $I_{\mathrm{D} 2} / I_{\mathrm{G}}$ intensity ratios that decreased with the increasing graphite content in the ceramic matrix. The $I_{\mathrm{D} 1} / I_{\mathrm{G}}$ ratio dropped from 2.69 for the pure ceramic to 1.24 for the $S i O C_{\mathrm{PhTES}} / \mathrm{C} 10 \mathrm{~g}$ sample, whereas $I_{\mathrm{D} 2} / I_{\mathrm{G}}$ decreased from 1.61 to 0.76 . Moreover, composites with graphite exhibit lower intensity 
of the D3 band compared to the pure ceramics. These results prove that the addition of graphite to the composites increased the content of the ordered carbon phase in the material, suggesting that the graphitic structure was hardly affected by the ultrasound treatment.

Table 3. Data obtained from the Raman spectra deconvolution of the investigated samples, band positions, band intensities $(I)$ (height of the fitted peak) and intensity ratio $\left(I_{\mathrm{D} 1} / I_{\mathrm{G}}\right.$ and $\left.I_{\mathrm{D} 2} / I_{\mathrm{G}}\right)$.

\begin{tabular}{|c|c|c|c|c|c|c|c|c|c|c|c|c|}
\hline \multirow{2}{*}{ Material } & \multicolumn{2}{|c|}{ D4 } & \multicolumn{2}{|c|}{ D1 } & \multicolumn{2}{|c|}{ D3 } & \multicolumn{2}{|c|}{ G } & \multicolumn{2}{|c|}{ D2 } & \multirow{2}{*}{$I_{\mathrm{D} 1 /} I_{\mathrm{G}}$} & \multirow{2}{*}{$I_{\mathrm{D} 2 /} I_{\mathrm{G}}$} \\
\hline & $\mathrm{cm}^{-1}$ & $I_{\mathrm{D} 4}$ & $\mathrm{~cm}^{-1}$ & $I_{\mathrm{D} 1}$ & $\mathrm{~cm}^{-1}$ & $I_{\mathrm{D} 3}$ & $\mathrm{~cm}^{-1}$ & $I_{G}$ & $\mathrm{~cm}^{-1}$ & $I_{\mathrm{D} 2}$ & & \\
\hline $\mathrm{SiOC}_{\text {PhTES }}$ & 1194 & 0.084 & 1333 & 0.98 & 1525 & 0.22 & 1575 & 0.36 & 1608 & 0.58 & 2.69 & 1.61 \\
\hline $\mathrm{SiOC}_{\mathrm{PhTES}} / \mathrm{C} 2 \mathrm{~g}$ & 1193 & 0.06 & 1327 & 1 & 1528 & 0.17 & 1580 & 0.48 & 1609 & 0.61 & 2.06 & 1.26 \\
\hline $\mathrm{SiOC}_{\mathrm{PhTES}} / \mathrm{C} 4 \mathrm{~g}$ & 1195 & 0.059 & 1332 & 0.88 & 1525 & 0.16 & 1571 & 0.57 & 1603 & 0.6 & 1.53 & 1.05 \\
\hline $\mathrm{SiOC}_{\mathrm{PhTES}} / \mathrm{C} 10 \mathrm{~g}$ & 1197 & 0.075 & 1333 & 0.84 & 1528 & 0.16 & 1580 & 0.68 & 1610 & 0.52 & 1.24 & 0.76 \\
\hline Graphite & - & - & 1348 & 0.22 & - & - & 1573 & 0.97 & 1611 & 0.04 & 0.22 & 0.04 \\
\hline
\end{tabular}

Furthermore, we tested the influence of ultrasounds on the size of graphite flakes used for the synthesis of the composites. In that case, we immersed graphitic powder into test tubes with isopropanol and subjected it to ultrasounds for a time of up to $2 \mathrm{~h}$ (analogous to the time used for composite blending). After drying, the morphology of the graphite powder was examined by SEM and no changes with respect to the pristine graphitic morphology were identified (see SEM Figure S4a,b, Supplementary Materials). This suggests that the structure of graphite was preserved in the composites.

In the second-order Raman spectra, the bands at $2700 \mathrm{~cm}^{-1}$ (2D) and $2900 \mathrm{~cm}^{-1}$ (D + G) were detected, i.e., the overtones of D-band along with combined D and G bands, respectively. The 2D band correlates with the number of stacked carbon layers that make up graphite clusters. The second-order Raman spectra are presented in more detail in Figure S3b (Supplementary Materials). Graphite exhibits a very pronounced $2 \mathrm{D}$ peak at $2702 \mathrm{~cm}^{-1}$, indicating stacked undamaged graphene layers. In contrast, the $\mathrm{SiOC}_{\mathrm{PhTES}}$ shows an asymmetric and blurred 2D peak, indicating high disorder in the carbon structure. With increasing graphite content in the composites, the 2D band becomes narrower and more intense, signifying increased content of a more ordered carbon phase. The overall Raman results do not indicate any damages in the graphitic structure provoked by the ultrasound-assisted synthesis method, confirming the results obtained by NMR and XRD analysis.

TEM imaging was performed in order to investigate more deeply the microstructure of the

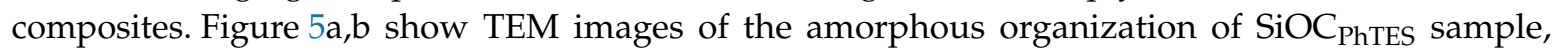
(typical for pure silicon oxycarbide pyrolyzed at $1000^{\circ} \mathrm{C}$ ). On the other hand, two separate phases, representing the amorphous $\mathrm{SiOC}$ and the more ordered carbon material, are observed for the $\mathrm{SiOC}_{\mathrm{PhTES}} / \mathrm{C} 10 \mathrm{~g}$ sample (Figure $5 \mathrm{c}, \mathrm{d}$ ).

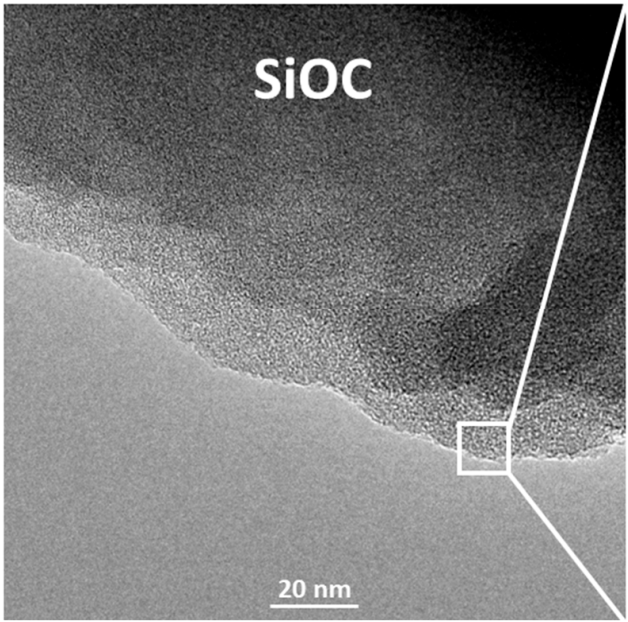

(a)

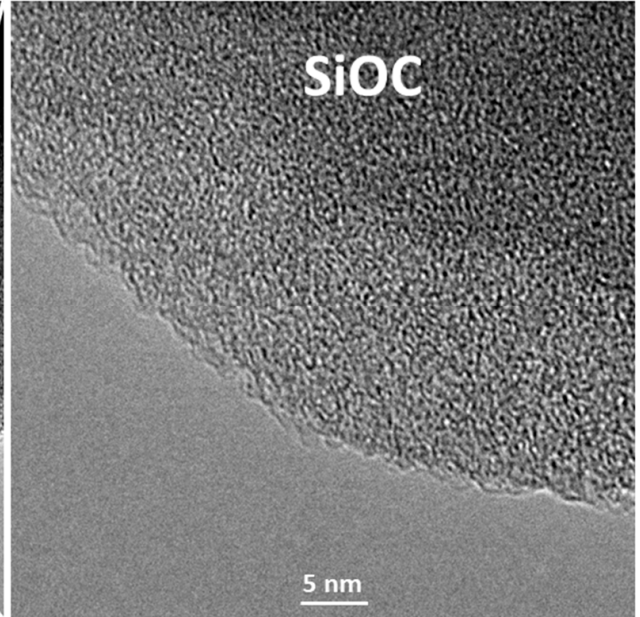

(b)

Figure 5. Cont. 


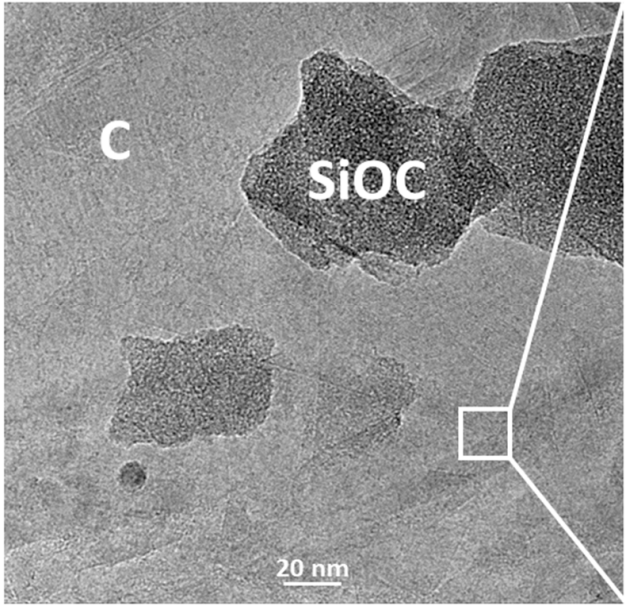

(c)

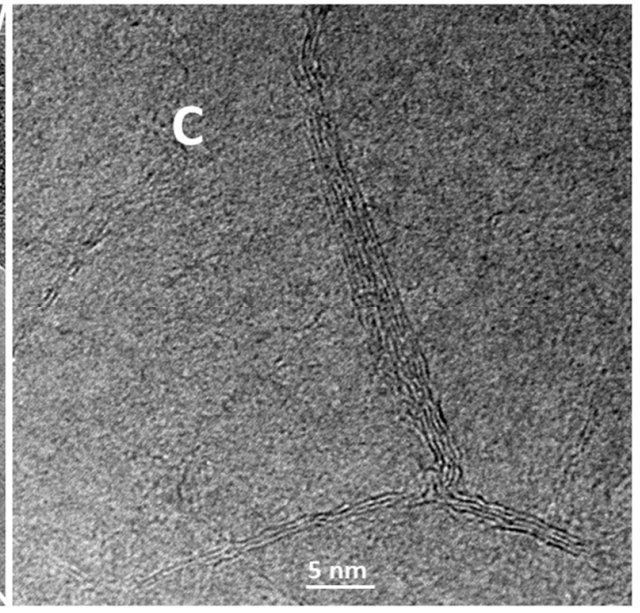

(d)

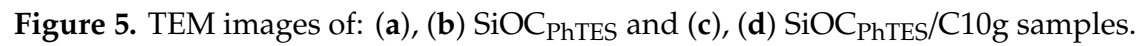

STEM-EDX measurements confirm the presence of a uniform silicon oxycarbide phase for the SiOC $_{\text {PhTES }}$ sample, and two separate phases for the $\mathrm{SiOC}_{\mathrm{PhTES}} / \mathrm{C} 10 \mathrm{~g}$ composite one, where only carbon is identified, and the second one, where carbon, silicon and oxygen dominate (Figure 6a,b).

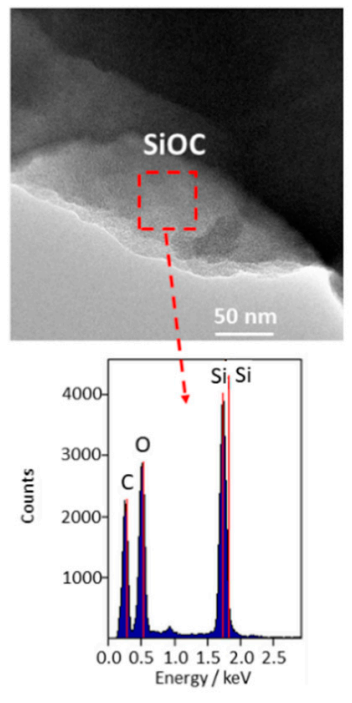

(a)

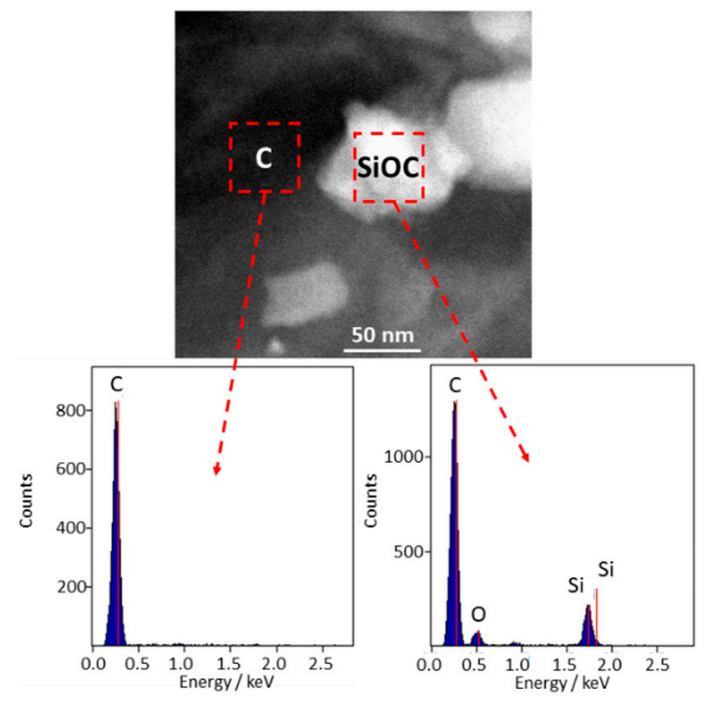

(b)

Figure 6. TEM images of: (a) $\mathrm{SiOC}_{\mathrm{PhTES}}$ and (b) $\mathrm{SiOC}_{\mathrm{PhTES}} / \mathrm{C} 10 \mathrm{~g}$ samples.

\section{Electrochemical Testing}

Figure 7a,b show CV plots obtained for the SiOC $\mathrm{PhTES} /$ graphite composites and pure components for comparison. During the first cycle, all the composites and pristine ceramic materials exhibited a small cathodic peak at $0.7 \mathrm{~V}$ (marked as (I) on the plot), which disappear in the following cycles. This corresponds to the formation of the solid-electrolyte interface (SEI) on the boundaries of the ceramic phase [69,70]. Further on the CV curves of the SiOC-based materials, a broad peak between 0 and $0.3 \mathrm{~V}$ (II), which corresponds to lithium insertion into the ceramic $[29,69,71]$, is present. The cathodic current in this range decreases with the increasing graphite content in the composites, but there are no pronounced peaks at 0.16 and $0.05 \mathrm{~V}$ as registered for pure graphite. The intensity of the peak (II) is dropping in the following cycles (Figure $7 \mathrm{~b}$ ), which corresponds to the stabilization of the lithium insertion [72]. On the anodic site of the CV of the composites, we observe peaks between 0 and $0.25 \mathrm{~V}$ 
(III) corresponding to graphite delithiation [73] and a broad plateau-like peak (IV) characteristic for a typical lithium extraction from the ceramic [71]. The intensity of the peaks observed on CV curves depends on the composition of the material and follows the trend of increasing graphite content. For graphite-rich composites, one may identify more pronounced peaks (III), while for graphite-poor composites the peak (IV) is more intense.

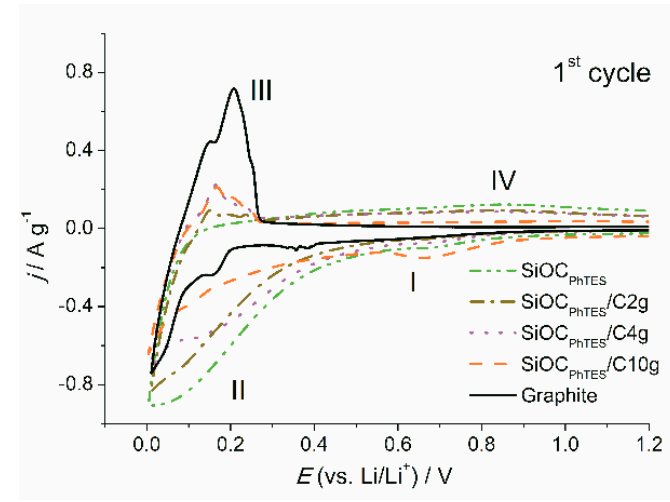

(a)

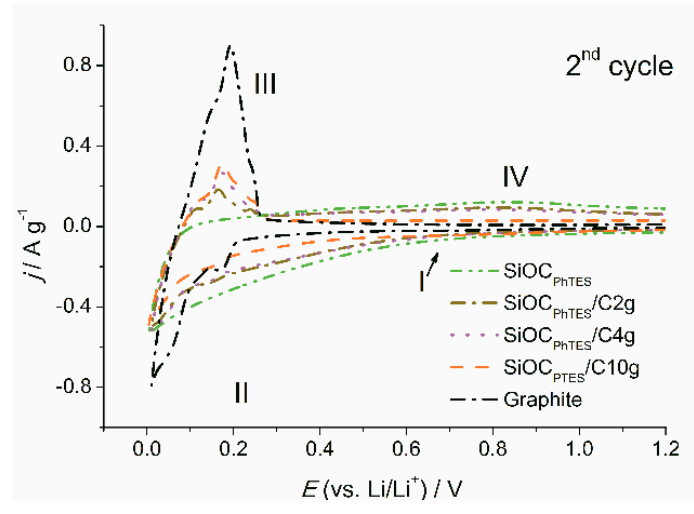

(b)

Figure 7. Cyclic voltammetry curves of the investigated materials: (a) first cycle, (b) second cycle; scan rate $0.1 \mathrm{mV} \mathrm{s}^{-1}$.

The capacity distribution over the potential range of $0-3 \mathrm{~V}$ and the Coulombic efficiencies were assessed from charge/discharge profiles. Figure $8 \mathrm{a}, \mathrm{b}$ show charge/discharge curves of the first and second cycles, respectively, while more detailed information is presented in Table 4 . The first cycle lithiation profiles of the $\mathrm{SiOC}_{\mathrm{PhTES}}, \mathrm{SiOC}_{\mathrm{PhTES}} / \mathrm{C} 2 \mathrm{~g}$ and $\mathrm{SiOC}_{\mathrm{PhTES}} / \mathrm{C}_{\mathrm{S}} \mathrm{g}$ samples are very similar. A different curve shape with a quasi-plateau at around $0.7 \mathrm{~V}$, related to SEI formation, is noticed for the $\mathrm{SiOC}_{\mathrm{PhTES}} / \mathrm{C} 10 \mathrm{~g}$ sample. Galvanostatic charge-discharge curves correspond well to the cyclic voltammetry curves. The trends of increasing length of the plateau, corresponding to delithiation of the graphitic phase, and a decrease in the delithiation potential with increasing graphite content in the ceramic matrix can be identified. A low delithiation potential is one of the features expected for LIC anodes. The curves of the $\mathrm{SiOC}_{\mathrm{PhTES}} / \mathrm{C} 2 \mathrm{~g}$ and $\mathrm{SiOC}_{\mathrm{PhTES}} / \mathrm{C} 4 \mathrm{~g}$ samples exhibit small plateaus in the $0.11-0.15 \mathrm{~V}$ voltage range, followed by a more rapid voltage increase, while the plateau recorded for the $\mathrm{SiOC}_{\mathrm{PhTES}} / \mathrm{C} 10 \mathrm{~g}$ composite is significantly longer, and the onset of the faster voltage rise is observed at $0.2 \mathrm{~V}$. This results in the higher capacity recovered below $0.5 \mathrm{~V}$ for the $\mathrm{SiOC}_{\mathrm{PhTES}} / \mathrm{C} 10 \mathrm{~g}$ sample compared to the composites and the pure ceramics.

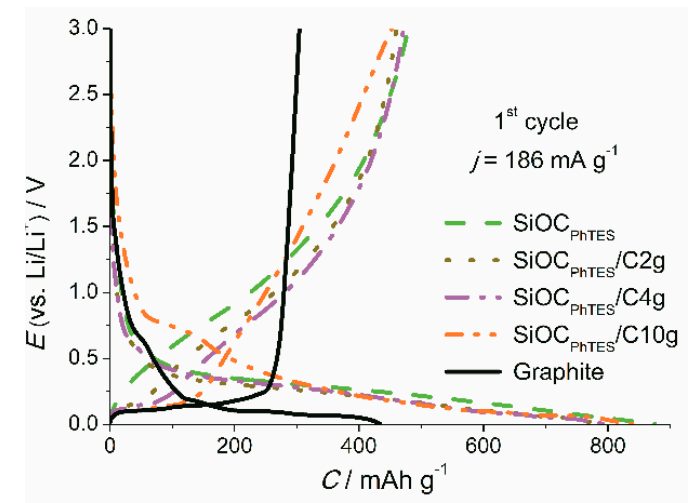

(a)

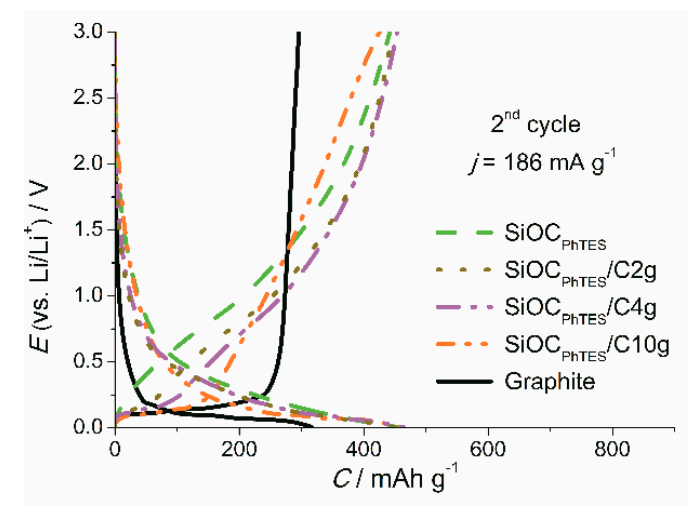

(b)

Figure 8. Galvanostatic charge-discharge curves of the investigated materials recorded at the current density (j) of $186 \mathrm{~mA} \mathrm{~g}^{-1}$ : (a) first, (b) second cycle. 
Table 4. Reversible $\mathrm{C}_{\text {rev }}$ and irreversible $\mathrm{C}_{\text {irrev }}$ capacity values of the first cycle upon polarization with $0.186 \mathrm{~A} \mathrm{~g}^{-1}$, Coulombic efficiency of the first cycle $\eta$ and the average delithiation capacities CD of graphite, ceramic and composite samples measured at different current rates (average capacity values calculated from data presented in Figure 9).

\begin{tabular}{|c|c|c|c|c|c|}
\hline \multirow{2}{*}{ Sample } & \multirow{2}{*}{$\begin{array}{c}\text { 1st Cycle } \\
\mathrm{C}_{\text {rev }} / \mathrm{mAh} \mathrm{g}^{-1}\end{array}$} & \multirow{2}{*}{$\begin{array}{c}\text { 1st Cycle } \\
\mathrm{C}_{\text {irrev }} / \mathrm{mAh} \mathrm{g}^{-1}\end{array}$} & \multirow{2}{*}{$\eta$} & \multicolumn{2}{|c|}{ Average CD } \\
\hline & & & & $1.86 \mathrm{~A} \mathrm{~g}^{-1}$ & $0.186 \mathrm{~A} \mathrm{~g}^{-1}$ \\
\hline Graphite & 304 & 129 & 70.2 & 108 & 268 \\
\hline $\mathrm{SiOC}_{\mathrm{PhTES}}$ & 479 & 396 & 54.7 & 218 & 402 \\
\hline $\mathrm{SiOC}_{\text {PhTES }} / \mathrm{C} 2 \mathrm{~g}$ & 472 & 320 & 59.6 & 214 & 423 \\
\hline $\mathrm{SiOC}_{\mathrm{PhTES}} / \mathrm{C} 4 \mathrm{~g}$ & 460 & 336 & 57.8 & 242 & 408 \\
\hline $\mathrm{SiOC}_{\mathrm{PhTES}} / \mathrm{C} 10 \mathrm{~g}$ & 452 & 386 & 53.9 & 293 & 372 \\
\hline
\end{tabular}

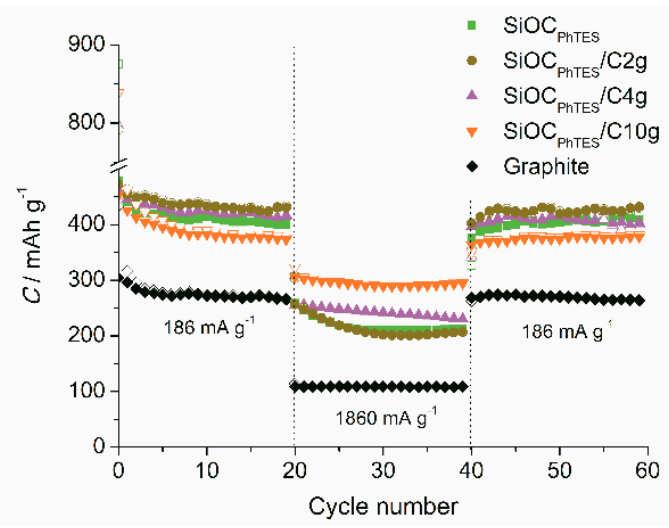

Figure 9. Lithiation (empty symbol) and delithiation (solid symbol) capacity upon extended cycling at $\mathrm{C} / 2$ and $5 \mathrm{C}$ rate for the investigated materials.

The electrochemical contribution of both components, namely SiOC and graphite, is unambiguously exposed on charge-discharge curves of the investigated composites, and the contribution of each part is proportional to its content. For graphite-poor samples, a small plateau originating from graphite, and a long ascending curve typical for ceramics can be noticed, while in the case of graphite-rich sample a much larger plateau is observed.

The charge/discharge profile allows one to evaluate the Coulombic efficiency of the material. One could expect that the first cycle efficiency (FCE) should increase with the addition of graphite to the composites. However, the graphite flakes used for composite preparation exhibit relatively low Coulombic efficiency of the first cycle (lower than reported by electrode suppliers $[74,75]$ or in literature $[76,77])$. This may be caused by lower crystallinity and higher surface area of the flakes than of graphite used in commercial batteries. Addition of small quantities of graphite seems to slightly increase the FCE (59.6\% and 57.8\% for the $\mathrm{SiOC}_{\mathrm{PhTES}} / \mathrm{C} 2 \mathrm{~g}$ and $\mathrm{SiOC}_{\mathrm{PhTES}} / \mathrm{C} 4 \mathrm{~g}$, respectively, compared to $54.7 \%$ for the pure ceramic). However, the sample with the highest graphite content, i.e., the $\mathrm{SiOC}_{\mathrm{PhTES}} / \mathrm{C} 10 \mathrm{~g}$, showed the FCE of only $53.9 \%$. This may be caused by higher activity at $0.7 \mathrm{~V}$ observed on the CV and GCD curves during the first cycle. In the following cycles, all studied materials show efficiency of over $99 \%$. Extended cycling of the electrodes at the $\mathrm{C} / 2$ and $5 \mathrm{C}$ current rates $\left(\mathrm{C}=372 \mathrm{~mA} \mathrm{~g}^{-1}\right)$ is presented in Figure 9. All the SiOC-based materials show better electrochemical performance than graphite. The difference is even more pronounced at high current rates. Note that for the $\mathrm{C} / 2$ rate the highest capacity is recorded for the composite with the lowest graphite content $\left(423 \mathrm{mAh} \mathrm{g}^{-1}\right.$ for $\left.\mathrm{SiOC}_{\mathrm{PhTES}} / \mathrm{C} 2 \mathrm{~g}\right)$, while for the $5 \mathrm{C}$ rate, the graphite-rich composite has the highest capacity ( $293 \mathrm{mAh} \mathrm{g}^{-1}$ for SiOC $\mathrm{PhTES} / \mathrm{C} 10 \mathrm{~g}$ compared to $218 \mathrm{mAh} \mathrm{g}^{-1}$ for the pure

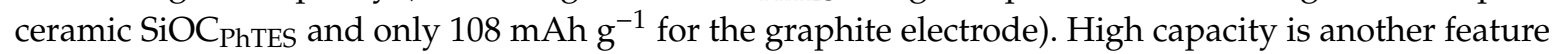
of anodes that are suitable for high power energy devices. Better electrochemical performance of the $\mathrm{SiOC}_{\mathrm{PhTES}} / \mathrm{C} 10 \mathrm{~g}$ sample compared to the $\mathrm{SiOC}_{\mathrm{PhTES}}$ one may follow from the carbon content in these 
materials. According to elemental analysis (Table 1), the amount of carbon increases from $37.4 \mathrm{wt}$.\% for pure ceramic to $68.7 \mathrm{wt}$ \% for the composites with the highest graphite content. A higher amount of carbon in the ceramic matrix leads to a higher electronic conductivity and a larger number of diffusion paths for lithium ions, crucial upon polarization with high currents. Slightly lower capacity showed by the $\mathrm{SiOC}_{\mathrm{PhTES}} / \mathrm{C} 10 \mathrm{~g}$ composites compared to the pure ceramic at the $\mathrm{C} / 2$ rate is probably due to a lower share of the active sites for lithium storage present in the ceramics [78]. Low capacity of pure graphite at a high current rate is often explained by material exfoliation caused by electrolyte penetration along with lithium ions [79].

To examine the phenomenon of high capacity at high currents for graphite rich composite, we took a closer look at the charge/discharge profiles collected upon polarization at a 5C rate (Figure 10). GCD curves presented in Figure 10 were recorded after 20 cycles at a C/2 rate in order to show a stable response of the electrodes with Coulombic efficiency of over $99 \%$. The shape of the composite curves at $5 \mathrm{C}$ exhibits the same tendency as the curves recorded at a C/2 rate (more extended plateau and a lower delithiation voltage for graphite-rich samples), except for the capacity value, which is the highest for the $\mathrm{SiOC}_{\mathrm{PhTES}} / \mathrm{C} 10 \mathrm{~g}$ electrode. These features make the material promising for the application in LIC. What is also essential for the potential application in LIC, is that this composite delivers the highest capacity below $0.5 \mathrm{~V}$.

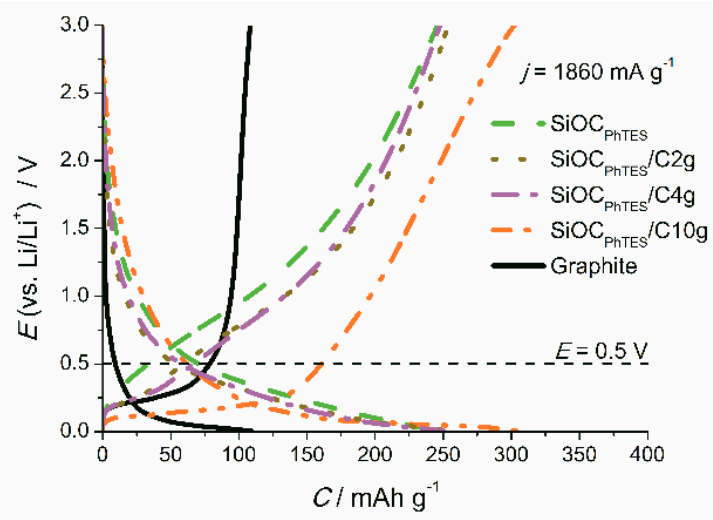

Figure 10. Galvanostatic charge-discharge curves of the investigated materials recorded at $1860 \mathrm{~mA} \mathrm{~g}^{-1}$.

In Table 5, the capacity values of the most popular potential anodes for LIC reported in the literature are presented. The focus was on the capacity measured at a $2 \mathrm{~A} \mathrm{~g}^{-1}$ current rate typical for testing of LIC [4], and voltage range below $0.5 \mathrm{~V}$. To the best of our knowledge, the SiOC $\mathrm{PhTES}_{\mathrm{C}} \mathrm{C} 10 \mathrm{~g}$ composite exhibits the highest capacity upon these conditions among all popular LIC anode materials. Our composite exhibits twice as high capacity as the competitive materials. Considering the potential range (0-3 V), our composite also shows a satisfactory capacity of almost $300 \mathrm{mAh} \mathrm{g}{ }^{-1}$.

Table 5. Capacity recovered below $0.5 \mathrm{~V}$ at high current rates for LIC anodic materials.

\begin{tabular}{|c|c|c|c|c|c|}
\hline \multirow{2}{*}{ Material } & \multirow{2}{*}{ Counter Electrode } & \multirow{2}{*}{ Current Rate/A $\mathbf{g}^{-1}$} & \multicolumn{2}{|c|}{ Capacity in the Voltage Range } & \multirow{2}{*}{ Ref. } \\
\hline & & & $0-0.5 \mathrm{~V} / \mathrm{mAh} \mathrm{g}^{-1}$ & $0-3 \mathrm{~V} / \mathrm{mAh} \mathrm{g}^{-1}$ & \\
\hline $\mathrm{MnO}_{2}$ /graphene aerogel & Li metal & 2 & $\sim 60$ & 257 & [14] \\
\hline TiC accordion & $\mathrm{AC}^{\mathrm{a}}$ & 1.3 & $\sim 50$ & $65(0-2.5 \mathrm{~V})$ & [80] \\
\hline $\mathrm{TiNb}_{2} \mathrm{O}_{7}$ nanorods & Li metal & 1.9 & $0^{\mathrm{b}}$ & 225 & [81] \\
\hline CTAB-Sn(IV)@ $\mathrm{Ti}_{3} \mathrm{C}_{2}$ & Li metal & 1 & $\sim 40$ & $\sim 480$ & [82] \\
\hline $\mathrm{Nb}_{2} \mathrm{O}_{5}$ nanorods film & Li metal & 2 & $0^{\mathrm{b}}$ & 154 & [83] \\
\hline LTO-graphene & Li metal & 1.75 & $0^{\mathrm{b}}$ & 180 & [84] \\
\hline N-doped graphene sheet & Li metal & 2 & $\sim 30$ & 205 & [85] \\
\hline $\mathrm{MnFe}_{2} \mathrm{O}_{4} /$ carbon & Li metal & 2 & $\sim 65$ & $\sim 600$ & [86] \\
\hline $\mathrm{BiVO}_{4}$ nanorods & Li metal & 2.3 & $\sim 70$ & $\sim 700$ & [87] \\
\hline $\mathrm{Fe}_{3} \mathrm{O}_{4} @$ carbon & Li metal & 2 & $\sim 10$ & $\sim 587$ & [88] \\
\hline $\mathrm{SiOC}$ & Li metal & 0.2 & $\sim 90$ & $238(0-1 \mathrm{~V})$ & [30] \\
\hline
\end{tabular}


Table 5. Cont.

\begin{tabular}{|c|c|c|c|c|c|}
\hline \multirow{2}{*}{ Material } & \multirow{2}{*}{ Counter Electrode } & \multirow{2}{*}{ Current Rate/A g ${ }^{-1}$} & \multicolumn{2}{|c|}{ Capacity in the Voltage Range } & \multirow{2}{*}{ Ref. } \\
\hline & & & $0-0.5 \mathrm{~V} / \mathrm{mAh}^{-1}$ & $0-3 \mathrm{~V} / \mathrm{mAh} \mathrm{g}^{-1}$ & \\
\hline Graphite & Li metal & 1.9 & 79 & 108 & Our work \\
\hline $\mathrm{SiOC}_{\text {PhTES }}$ & Li metal & 1.9 & 34 & 246 & Our work \\
\hline $\mathrm{SiOC}_{\mathrm{PhTES}} / \mathrm{C} 10 \mathrm{~g}$ & Li metal & 1.9 & 161 & 294 & Our work \\
\hline
\end{tabular}

$\mathrm{AC}^{\mathrm{a}}$-Activated carbon; ${ }^{\mathrm{b}}$ measurements started above $0.5 \mathrm{~V}$, so we assume negligible capacity below $0.5 \mathrm{~V}$. “ ” sign

appears for the values assessed from the graph presented in the cited paper.

\section{Conclusions}

In this work, we evaluated various graphite-ceramic based composites with different graphite content for potential application as anodes in LIC. The materials were prepared by a novel method utilizing high power ultrasounds. Sonication facilitates the gelation process and uniform distribution of graphite flakes within the preceramic polymer. Silicon oxycarbide is an electrochemically active component contributing to the capacity of composites and plays the additional role of a matrix for graphitic flakes, causing the stabilization of the electrochemical response at high current rates. Moreover, the addition of graphite to SiOC shifts lithiation and delithiation processes towards lower potentials in comparison to the pure SiOC. The best performing material seems to be the $\mathrm{SiOC}_{\mathrm{PhTES}} / \mathrm{C} 10 \mathrm{~g}$ one, i.e., the composite with the highest investigated graphite content. This material is characterized by a high capacity of $294 \mathrm{mAh} \mathrm{g}^{-1}$ at a 5C current rate, among which over $160 \mathrm{mAh} \mathrm{g}^{-1}$ is recovered below $0.5 \mathrm{~V}$ vs. $\mathrm{Li} / \mathrm{Li}^{+}$. This makes the $\mathrm{SiOC}$ PhTES/C10g material a potential candidate for anodes used in high power energy storage devices, e.g., lithium-ion capacitors.

Supplementary Materials: The following are available online at http://www.mdpi.com/1996-1944/13/19/4302/s1,

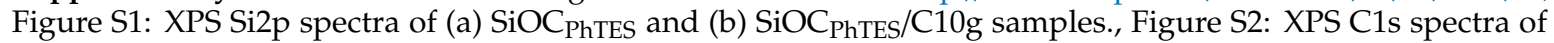
(a) $\mathrm{SiOC}_{\mathrm{PhTES}}$ and (b) SiOC $\mathrm{PhTES} / \mathrm{C} 10 \mathrm{~g}$ samples., Figure S3: (a) Deconvolution of Raman spectra of the pure graphite, (b) second-order Raman spectra of graphite, ceramic and SiOC/graphite composites, Figure S4: pictures of (a) graphite flakes, (b) graphite flakes after $2 \mathrm{~h}$ sonication in isopropanol, Table S1: Data obtained from the deconvolution of Raman spectra.

Author Contributions: Conceptualization, M.W.-Z.; methodology, D.K., M.G.-Z., G.T., M.W.-Z.; formal analysis, D.K., M.G.-Z., G.T., M.W.-Z.; investigation, D.K., M.G.-Z., M.W.-Z.; resources, M.G.-Z., M.W.-Z.; data curation, D.K. M.W.-Z; writing—original draft preparation, D.K., M.G.-Z., G.T., M.W.-Z.; writing—review and editing, D.K., M.G.-Z. M.W.-Z.; visualization, D.K., G.T., M.W.-Z.; supervision, M.W.-Z.; project administration, M.W.-Z.; funding acquisition, M.W.-Z. All authors have read and agreed to the published version of the manuscript.

Funding: This work is supported by Foundation for Polish Science under REINTEGRATION programme, project No POIR.04.04.00-00-4582/17-00.

Conflicts of Interest: The authors declare no conflict of interest.

\section{References}

1. Service, R.F. New “Supercapacitor” Promises to Pack More Electrical Punch. Science 2006, 313, 902. [CrossRef] [PubMed]

2. González, A.; Goikolea, E.; Barrena, J.A.; Mysyk, R. Review on supercapacitors: Technologies and materials. Renew. Sustain. Energy Rev. 2016, 58, 1189-1206. [CrossRef]

3. Amatucci, G.G.; Badway, F.; Du Pasquier, A.; Zheng, T. An Asymmetric Hybrid Nonaqueous Energy Storage Cell. J. Electrochem. Soc. 2001, 148, A930-A939. [CrossRef]

4. Stoller, M.D.; Ruoff, R.S. Best practice methods for determining an electrode material's performance for ultracapacitors. Energy Environ. Sci. 2010, 3, 1294-1301. [CrossRef]

5. Wang, G.; Zhang, L.; Zhang, J. A review of electrode materials for electrochemical supercapacitors. Chem. Soc. Rev. 2012, 41, 797-828. [CrossRef] [PubMed]

6. Vol'fkovich, Y.M.; Serdyuk, T.M. Electrochemical Capacitors. Russ. J. Electrochem. 2002, 38, 1043-1068. [CrossRef]

7. Augustyn, V.; Simon, P.; Dunn, B. Pseudocapacitive oxide materials for high-rate electrochemical energy storage. Energy Environ. Sci. 2014, 7, 1597-1614. [CrossRef]

8. Naoi, K.; Ishimoto, S.; Miyamoto, J.I.; Naoi, W. Second generation "nanohybrid supercapacitor": Evolution of capacitive energy storage devices. Energy Environ. Sci. 2012, 5, 9363-9373. [CrossRef] 
9. Li, B.; Zheng, J.; Zhang, H.; Jin, L.; Yang, D.; Lv, H.; Shen, C.; Shellikeri, A.; Zheng, Y.; Gong, R.; et al. Electrode Materials, Electrolytes, and Challenges in Nonaqueous Lithium-Ion Capacitors. Adv. Mater. 2018, 30, 1705670. [CrossRef]

10. Li, G.; Yang, Z.; Yin, Z.; Guo, H.; Wang, Z.; Yan, G.; Liu, Y.; Li, L.; Wang, J. Non-aqueous dual-carbon lithium-ion capacitors: A review. J. Mater. Chem. A 2019, 7, 15541-15563. [CrossRef]

11. Wang, H.; Zhu, C.; Chao, D.; Yan, Q.; Fan, H.J. Nonaqueous Hybrid Lithium-Ion and Sodium-Ion Capacitors. Adv. Mater. 2017, 29, 1702093. [CrossRef] [PubMed]

12. Xu, N.; Sun, X.; Zhang, X.; Wang, K.; Ma, Y. A two-step method for preparing Li4Ti5O12-graphene as an anode material for lithium-ion hybrid capacitors. RSC Adv. 2015, 5, 94361-94368. [CrossRef]

13. Li, Y.; Wang, R.; Zheng, W.; Zhao, Q.; Sun, S.; Ji, G.; Li, S.; Fan, X.; Xu, C. Design of Nb2O5/graphene hybrid aerogel as polymer binder-free electrodes for lithium-ion capacitors. Mater. Technol. 2020, 35, 625-634. [CrossRef]

14. Yang, H.; Zhang, C.; Meng, Q.; Cao, B.; Tian, G. Pre-lithiated manganous oxide/graphene aerogel composites as anode materials for high energy density lithium ion capacitors. J. Power Sources 2019, 431, 114-124. [CrossRef]

15. Zhao, X.; Zhang, X.; Li, C.; Sun, X.; Liu, J.; Wang, K.; Ma, Y. High-Performance Lithium-Ion Capacitors Based on CoO-Graphene Composite Anode and Holey Carbon Nanolayer Cathode. ACS Sustain. Chem. Eng. 2019, 7, 11275-11283. [CrossRef]

16. Gao, J.; Li, Y.; Liu, Y.; Jiao, S.; Li, J.; Wang, G.; Zeng, S.; Zhang, G. The dual-function sacrificing template directed formation of MoS2/C hybrid nanotubes enabling highly stable and ultrafast sodium storage. J. Mater. Chem. A 2019, 7, 18828-18834. [CrossRef]

17. Chen, H.; Zhu, X.; Chang, Y.; Cai, J.; Zhao, R. 3D flower-like CoS hierarchitectures recycled from spent $\mathrm{LiCoO} 2$ batteries and its application in electrochemical capacitor. Mater. Lett. 2018, 218, 40-43. [CrossRef]

18. Cao, W.J.; Zheng, J.P. Li-ion capacitors with carbon cathode and hard carbon/stabilized lithium metal powder anode electrodes. J. Power Sources 2012, 213, 180-185. [CrossRef]

19. Schroeder, M.; Winter, M.; Passerini, S.; Balducci, A. On the cycling stability of lithium-ion capacitors containing soft carbon as anodic material. J. Power Sources 2013, 238, 388-394. [CrossRef]

20. Khomenko, V.; Raymundo-Piñero, E.; Béguin, F. High-energy density graphite/AC capacitor in organic electrolyte. J. Power Sources 2008, 177, 643-651. [CrossRef]

21. Kottegoda, I.R.M.; Kadoma, Y.; Ikuta, H.; Uchimoto, Y.; Wakihara, M. Enhancement of rate capability in graphite anode by surface modification with zirconia. Electrochem. Solid-State Lett. 2002, 5, A275-A278. [CrossRef]

22. Sivakkumar, S.R.; Nerkar, J.Y.; Pandolfo, A.G. Rate capability of graphite materials as negative electrodes in lithium-ion capacitors. Electrochim. Acta 2010, 55, 3330-3335. [CrossRef]

23. Buqa, H.; Goers, D.; Holzapfel, M.; Spahr, M.E.; Novák, P. High Rate Capability of Graphite Negative Electrodes for Lithium-Ion Batteries. J. Electrochem. Soc. 2005, 152, A474-A481. [CrossRef]

24. Ma, C.; Zhao, Y.; Li, J.; Song, Y.; Shi, J.; Guo, Q.; Liu, L. Synthesis and electrochemical properties of artificial graphite as an anode for high-performance lithium-ion batteries. Carbon 2013, 64, 553-556. [CrossRef]

25. Yeo, J.S.; Park, T.H.; Seo, M.H.; Miyawaki, J.; Mochida, I.; Yoon, S.H. Enhancement of the rate capability of graphite via the introduction of boron-oxygen functional groups. Int. J. Electrochem. Sci. 2013, 8, 1308-1315.

26. Mera, G.; Navrotsky, A.; Sen, S.; Kleebe, H.J.; Riedel, R. Polymer-derived SiCN and SiOC ceramics-structure and energetics at the nanoscale. J. Mater. Chem. A 2013, 1, 3826-3836. [CrossRef]

27. Pradeep, V.S.; Graczyk-Zajac, M.; Riedel, R.; Soraru, G.D. New insights in to the lithium storage mechanism in polymer derived SiOC anode materials. Electrochim. Acta 2014, 119, 78-85. [CrossRef]

28. Pradeep, V.S.; Graczyk-Zajac, M.; Wilamowska, M.; Riedel, R.; Soraru, G.D. Influence of pyrolysis atmosphere on the lithium storage properties of carbon-rich polymer derived SiOC ceramic anodes. Solid State Ion. 2014, 262, 22-24. [CrossRef]

29. Wilamowska-Zawlocka, M.; Puczkarski, P.; Grabowska, Z.; Kaspar, J.; Graczyk-Zajac, M.; Riedel, R.; Sorarù, G.D. Silicon oxycarbide ceramics as anodes for lithium ion batteries: Influence of carbon content on lithium storage capacity. RSC Adv. 2016, 6, 104597-104607. [CrossRef]

30. Halim, M.; Liu, G.; Ardhi, R.E.A.; Hudaya, C.; Wijaya, O.; Lee, S.H.; Kim, A.Y.; Lee, J.K. Pseudocapacitive Characteristics of Low-Carbon Silicon Oxycarbide for Lithium-Ion Capacitors. ACS Appl. Mater. Interfaces 2017, 9, 20566-20576. [CrossRef] 
31. Jang, J.; Kim, H.; Lim, H.; jae Kim, K.; Jung, H.G.; Kim, S.O.; Choi, W. Surfactant-based selective assembly approach for Si-embedded silicon oxycarbide composite materials in lithium-ion batteries. Chem. Eng. J. 2020, 401, 126091. [CrossRef]

32. Kaspar, J.; Graczyk-Zajac, M.; Lauterbach, S.; Kleebe, H.J.; Riedel, R. Silicon oxycarbide/nano-silicon composite anodes for Li-ion batteries: Considerable influence of nano-crystalline vs. nano-amorphous silicon embedment on the electrochemical properties. J. Power Sources 2014, 269, 164-172. [CrossRef]

33. Tolosa, A.; Widmaier, M.; Krüner, B.; Griffin, J.M.; Presser, V. Continuous silicon oxycarbide fiber mats with tin nanoparticles as a high capacity anode for lithium-ion batteries. Sustain. Energy Fuels 2018, 2, 215-228. [CrossRef]

34. Dubey, R.J.-C.; Sasikumar, P.V.W.; Krumeich, F.; Blugan, G.; Kuebler, J.; Kravchyk, K.V.; Graule, T.; Kovalenko, M.V. Silicon Oxycarbide-Tin Nanocomposite as a High-Power-Density Anode for Li-Ion Batteries. Adv. Sci. 2019, 6, 1901220. [CrossRef] [PubMed]

35. Dubey, R.J.C.; Sasikumar, P.V.W.; Cerboni, N.; Aebli, M.; Krumeich, F.; Blugan, G.; Kravchyk, K.V.; Graule, T.; Kovalenko, M.V. Silicon oxycarbide-antimony nanocomposites for high-performance Li-ion battery anodes. Nanoscale 2020, 12, 13540-13547. [CrossRef]

36. Lee, Y.; Lee, K.Y.; Choi, W. One-Pot Synthesis of Antimony-Embedded Silicon Oxycarbide Materials for High-Performance Sodium-Ion Batteries. Adv. Funct. Mater. 2017, 27, 1702607. [CrossRef]

37. Kolb, R.; Fasel, C.; Liebau-Kunzmann, V.; Riedel, R. SiCN/C-ceramic composite as anode material for lithium ion batteries. J. Eur. Ceram. Soc. 2006, 26, 3903-3908. [CrossRef]

38. Graczyk-Zajac, M.; Fasel, C.; Riedel, R. Polymer-derived-SiCN ceramic/graphite composite as anode material with enhanced rate capability for lithium ion batteries. J. Power Sources 2011, 196, 6412-6418. [CrossRef]

39. Lehman, J.H.; Hurst, K.E.; Singh, G.; Mansfield, E.; Perkins, J.D.; Cromer, C.L. Core-shell composite of SiCN and multiwalled carbon nanotubes from toluene dispersion. J. Mater. Sci. 2010, 45, 4251-4254. [CrossRef]

40. Nowak, A.P.; Wicikowska, B.; Lisowska-Oleksiak, A. New ceramic materials derived from pyrolyzed poly(1,2-dimethylsilazane) and starch as a potential anode for Li-ion batteries. Solid State Ionics 2014, 263, 131-139. [CrossRef]

41. Wilamowska, M.; Graczyk-Zajac, M.; Riedel, R. Composite materials based on polymer-derived SiCN ceramic and disordered hard carbons as anodes for lithium-ion batteries. J. Power Sources 2013, 244, 80-86. [CrossRef]

42. Li, Y.; Hu, Y.; Lu, Y.; Zhang, S.; Xu, G.; Fu, K.; Li, S.; Chen, C.; Zhou, L.; Xia, X.; et al. One-dimensional $\mathrm{SiOC/C}$ composite nanofibers as binder-free anodes for lithium-ion batteries. J. Power Sources 2014, 254, 33-38. [CrossRef]

43. Bhandavat, R.; Singh, G. Stable and efficient li-ion battery anodes prepared from polymer-derived silicon oxycarbide-carbon nanotube shell/core composites. J. Phys. Chem. C 2013, 117, 11899-11905. [CrossRef]

44. David, L.; Bhandavat, R.; Barrera, U.; Singh, G. Silicon oxycarbide glass-graphene composite paper electrode for long-cycle lithium-ion batteries. Nat. Commun. 2016, 7, 10998. [CrossRef] [PubMed]

45. Ahn, D.; Raj, R. Cyclic stability and C-rate performance of amorphous silicon and carbon based anodes for electrochemical storage of lithium. J. Power Sources 2011, 196, 2179-2186. [CrossRef]

46. Wen, Q.; Yu, Z.; Riedel, R. The fate and role of in situ formed carbon in polymer-derived ceramics. Prog. Mater. Sci. 2020, 109, 100623. [CrossRef]

47. Wilamowska, M.; Pradeep, V.S.; Graczyk-Zajac, M.; Riedel, R.; Sorarù, G.D. Tailoring of SiOC composition as a way to better performing anodes for Li-ion batteries. Solid State Ion. 2014, 260, 94-100. [CrossRef]

48. Bahloul-Hourlier, D.; Latournerie, J.; Dempsey, P. Reaction pathways during the thermal conversion of polysiloxane precursors into oxycarbide ceramics. J. Eur. Ceram. Soc. 2005, 25, 979-985. [CrossRef]

49. Liu, C.; Meng, X.; Zhang, X.; Hong, C.; Han, J.; Han, W.; Xu, B.; Dong, S.; Du, S. High temperature structure evolution of macroporous SiOC ceramics prepared by a sol-gel method. Ceram. Int. 2015, 41, 11091-11096. [CrossRef]

50. Latournerie, J.; Dempsey, P.; Hourlier-Bahloul, D.; Bonnet, J.P. Silicon oxycarbide glasses: Part 1thermochemical stability. J. Am. Ceram. Soc. 2006, 89, 1485-1491. [CrossRef]

51. Sorarù, G.D.; Modena, S.; Guadagnino, E.; Colombo, P.; Egan, J.; Pantano, C. Chemical Durability of Silicon Oxycarbide Glasses. J. Am. Ceram. Soc. 2002, 85, 1529-1536. [CrossRef]

52. Önneby, C.; Pantano, C.G. Silicon oxycarbide formation on $\mathrm{SiC}$ surfaces and the $\mathrm{SiC} / \mathrm{SiO} 2$ interface. J. Vac. Sci. Technol. A Vac. Surf. Film 1997, 15, 1597-1602. [CrossRef] 
53. Meera, K.; Yang, C.S.; Choi, C.K. Bonding structure and electrical properties of SiOC(-H) films deposited with a methyltrimethoxysilane precursor by using inductively coupled plasma chemical vapor deposition. J. Korean Phys. Soc. 2006, 48, 1713-1718.

54. Bashouti, M.Y.; Paska, Y.; Puniredd, R.; Stelzner, T. Silicon nanowires terminated with methyl functionalities exhibit stronger Si-C bonds than equivalent 2D surfaces. Phys. Chem. Chem. Phys. 2009, 11, 3845-3848. [CrossRef] [PubMed]

55. Blyth, R.I.R.; Buqa, H.; Netzer, F.P.; Ramsey, M.G.; Besenhard, J.O. XPS studies of graphite electrode materials for lithium ion batteries. Appl. Surf. Sci. 2000, 167, 99-106. [CrossRef]

56. Abass, M.A.; Syed, A.A.; Gervais, C.; Singh, G. Synthesis and electrochemical performance of a polymer-derived silicon oxycarbide/boron nitride nanotube composite. RSC Adv. 2017, 7, 21576-21584. [CrossRef]

57. Renlund, G.M.; Prochazka, S.; Doremus, R.H. Silicon oxycarbide glasses: Part II. Structure and properties. J. Mater. Res. 1991, 6, 2723-2734. [CrossRef]

58. Wu, N.L.; Phillips, J. XRD evidence of preferental orientation of platinium crystallites on graphite. Surf. Sci. 1987, 184, 463-482. [CrossRef]

59. Liou, Y.J.; Huang, W.J. High Temperature Phase Transitions of Graphene Oxide Paper from Graphite Oxide Solution. J. Mater. Sci. Technol. 2014, 30, 1088-1091. [CrossRef]

60. Li, J.; Lu, K.; Lin, T.; Shen, F. Preparation of Micro-/Mesoporous SiOC Bulk Ceramics. J. Am. Ceram. Soc. 2015, 98, 1753-1761. [CrossRef]

61. Sadezky, A.; Muckenhuber, H.; Grothe, H.; Niessner, R.; Pöschl, U. Raman microspectroscopy of soot and related carbonaceous materials: Spectral analysis and structural information. Carbon 2005, 43, 1731-1742. [CrossRef]

62. Zhao, D.; Zhang, J.; Wang, G.; Xu, R.; Wang, H.; Zhong, J. Carbon structure in blast furnace dusts characterized by raman spectroscope and its links with combustion reactivity. In Advances in Materials Science for Environmental and Energy Technologies VI: Ceramic Transactions; Ohji, T., Matyas, J., Colorado, H., Kanakala, R., Eds.; Wiley Online Library: Hoboken, NJ, USA, 2017; Volume 262, pp. 69-75.

63. Tuinstra, F.; Koenig, J. Raman Spectrum of Graphite. J. Chem. Phys. 1970, 53, 1126-1130. [CrossRef]

64. Wang, Y.; Alsmeyer, D.C.; McCreery, R.L. Raman Spectroscopy of Carbon Materials: Structural Basis of Observed Spectra. Chem. Mater. 1990, 2, 557-563. [CrossRef]

65. Rosenburg, F.; Ionescu, E.; Nicoloso, N.; Riedel, R. High-temperature Raman spectroscopy of nano-crystalline carbon in silicon oxycarbide. Materials 2018, 11, 93. [CrossRef] [PubMed]

66. Dippel, B.; Jander, H.; Heintzenberg, J. NIR FT Raman spectroscopic study of flame soot. Phys. Chem. Chem. Phys. 1999, 1, 4707-4712. [CrossRef]

67. Cuesta, A.; Dhamelincourt, P.; Laureyns, J.; Martínez-Alonso, A.; Tascón, J.M.D. Raman microprobe studies on carbon materials. Carbon 1994, 32, 1523-1532. [CrossRef]

68. Eckmann, A.; Felten, A.; Mishchenko, A.; Britnell, L.; Krupke, R.; Novoselov, K.S.; Casiraghi, C. Probing the nature of defects in graphene by Raman spectroscopy. Nano Lett. 2012, 12, 3925-3930. [CrossRef]

69. Lv, P.; Zhao, H.; Gao, C.; Du, Z.; Wang, J.; Liu, X. SiOx-C dual-phase glass for lithium ion battery anode with high capacity and stable cycling performance. J. Power Sources 2015, 274, 542-550. [CrossRef]

70. Xia, K.; Wu, Z.; Xuan, C.; Xiao, W.; Wang, J.; Wang, D. Effect of $\mathrm{KOH}$ etching on the structure and electrochemical performance of SiOC anodes for lithium-ion batteries. Electrochim. Acta 2017, 245, 287-295. [CrossRef]

71. Graczyk-Zajac, M.; Toma, L.; Fasel, C.; Riedel, R. Carbon-rich SiOC anodes for lithium-ion batteries: Part I. Influence of material UV-pre-treatment on high power properties. Solid State Ion. 2012, 225, 522-526. [CrossRef]

72. Fukui, H.; Harimoto, Y.; Akasaka, M.; Eguchi, K. Lithium Species in Electrochemically Lithiated and Delithiated Silicon Oxycarbides. Appl. Mater. Interfaces 2014, 6, 12827-12836. [CrossRef]

73. Levi, M.D.; Aurbach, D. Simultaneous measurements and modeling of the electrochemical impedance and the cyclic voltammetric characteristics of graphite electrodes doped with lithium. J. Phys. Chem. B 1997, 101, 4630-4640. [CrossRef]

74. MSE Supplies LLC. Natural Graphite Product Information. Available online: https://www.msesupplies. com/products/natural-graphite-powder-lithium-ion-battery-anode-a?variant=7138017860 (accessed on 4 March 2020). 
75. Pyrotek Inc. Battery-Grade Graphite Product Information. Available online: https://www.pyrotek.com/ primary-solutions/battery-materials (accessed on 4 March 2020).

76. Mao, C.; Wood, M.; David, L.; An, S.J.; Sheng, Y.; Du, Z.; Meyer, H.M.; Ruther, R.E.; Wood, D.L. Selecting the Best Graphite for Long-Life, High-Energy Li-Ion Batteries. J. Electrochem. Soc. 2018, 165, A1837-A1845. [CrossRef]

77. Bai, L.Z.; Zhao, D.L.; Zhang, T.M.; Xie, W.G.; Zhang, J.M.; Shen, Z.M. A comparative study of electrochemical performance of graphene sheets, expanded graphite and natural graphite as anode materials for lithium-ion batteries. Electrochim. Acta 2013, 107, 555-561. [CrossRef]

78. Graczyk-Zajac, M.; Reinold, L.M.; Kaspar, J.; Sasikumar, P.V.W.; Soraru, G.D.; Riedel, R. New insights into understanding irreversible and reversible lithium storage within SIOC and SICN ceramics. Nanomaterials 2015, 5, 233-245. [CrossRef] [PubMed]

79. Aurbach, D.; Zinigrad, E.; Cohen, Y.; Teller, H. A short review of failure mechanisms of lithium metal and lithiated graphite anodes in liquid electrolyte solutions. Solid State Ion. 2002, 148, 405-416. [CrossRef]

80. Li, C.; Zhang, X.; Wang, K.; Sun, X.; Ma, Y. Accordion-like titanium carbide (MXene) with high crystallinity as fast intercalative anode for high-rate lithium-ion capacitors. Chinese Chem. Lett. 2020, 31, 1009-1013. [CrossRef]

81. Deng, B.; Dong, H.; Lei, T.; Yue, N.; Xiao, L.; Liu, J. Post-annealing tailored 3D cross-linked TiNb2O7 nanorod electrode: Towards superior lithium storage for flexible lithium-ion capacitors. Sci. China Mater. 2020, 63, 492-504. [CrossRef]

82. Luo, J.; Zhang, W.; Yuan, H.; Jin, C.; Zhang, L.; Huang, H.; Liang, C.; Xia, Y.; Zhang, J.; Gan, Y.; et al. Pillared Structure Design of MXene with Ultralarge Interlayer Spacing for High-Performance Lithium-Ion Capacitors. ACS Nano 2017, 11, 2459-2469. [CrossRef]

83. Deng, B.; Lei, T.; Zhu, W.; Xiao, L.; Liu, J. In-Plane Assembled Orthorhombic Nb2O5 Nanorod Films with High-Rate Li+ Intercalation for High-Performance Flexible Li-Ion Capacitors. Adv. Funct. Mater. 2018, 28, 1704330. [CrossRef]

84. Wang, G.; Lu, C.; Zhang, X.; Liu, B.; Xia, M.; Gou, H.; Xin, G.; Lian, J.; Zhang, Y. Toward Ultrafast Lithium Ion Capacitors: A Novel Atomic Layer Deposition Seeded Preparation of Li4Ti5O12 /Graphene Anode. Nano Energy 2017, 36, 46-57. [CrossRef]

85. Wang, R.; Zhao, Q.; Zheng, W.; Ren, Z.; Hu, X.; Li, J.; Lu, L.; Hu, N.; Molenda, J.; Liu, X.; et al. Achieving high energy density in a $4.5 \mathrm{v}$ all nitrogen-doped graphene based lithium-ion capacitor. J. Mater. Chem. A 2019, 7, 19909-19921. [CrossRef]

86. Lee, W.S.V.; Peng, E.; Li, M.; Huang, X.; Xue, J.M. Rational design of stable 4 V lithium ion capacitor. Nano Energy 2016, 27, 202-212. [CrossRef]

87. Dubal, D.P.; Jayaramulu, K.; Zboril, R.; Fischer, R.A.; Gomez-Romero, P. Unveiling BiVO4 nanorods as a novel anode material for high performance lithium ion capacitors: Beyond intercalation strategies. J. Mater. Chem. A 2018, 6, 6096-6106. [CrossRef]

88. Han, C.; Xu, L.; Li, H.; Shi, R.; Zhang, T.; Li, J.; Wong, C.P.; Kang, F.; Lin, Z.; Li, B. Biopolymer-assisted synthesis of 3D interconnected Fe3O4@carbon core@shell as anode for asymmetric lithium ion capacitors. Carbon 2018, 140, 296-305. [CrossRef]

(C) 2020 by the authors. Licensee MDPI, Basel, Switzerland. This article is an open access article distributed under the terms and conditions of the Creative Commons Attribution (CC BY) license (http://creativecommons.org/licenses/by/4.0/). 